\title{
Prevalence of Gum Infection and Halitosis Among the People of Madinah, Kingdom of Saudi Arabia
}

Badr Othman

\section{ABSTRACT}

Aim: This study was conducted to describe traumatic psychosocial impacts due to gingivitis and halitosis people faces and its relation to visiting dental clinics for aids from Madinah, Kingdom of Saudi Arabia.

Materials and methods: The cross-sectional study was conducted in a random sample of 240 people. Among them, 9 participants were excluded because of the lack of information and total 231 participants (134 males and 97 females) included in the study. The data was collected using a pretested structured questionnaire. The questionnaire was distributed electronically among the people living all over the Madinah, Kindom of Saudi Arabia.

Results: Mean age of the participant was 34.5. A maximum number of participants $(70.6 \%)$ told the reason of bad odor was poor oral hygiene and could be get rid by home care $(70.1 \%)$. Teeth pain $(84.4 \%)$ was the main cause to visit the dentist. Males were more ashamed of bad odor compared to female, and there was a significant relationship between gender and social impact $p=0.001$. Participants having gum infection were more ashamed in the society compared to the participants not having any gum infection $(p=0.001)$. Smokers were also more ashamed as compared to nonsmokers $(p=0.045)$.

Conclusion: The patients who had gum diseases and smoking developed more psychosocial effect in the society, and it is due to halitosis develop either due to gum disease or smoking. So the main reason of psychosocial trauma is that indirect effect of halitosis, which produced due to gum infection.

Clinical impact: People suffering from gingivitis and halitosis go to psychological trauma and they need a clinical solution to overcome from these.

Keywords: Gum infection, Halitosis, Periodontitis, Smokers.

How to cite this article: Othman B. Gum Infection and Halitosis Among the People of Madinah, Kingdom of Saudi Arabia. World J Dent 2018;9(5):377-381.

Source of support: Nil

Conflict of interest: None

Department of Preventive Dental Sciences, College of Dentistry, Taibah University, Al Madinah Al Munawwarah, Kingdom of Saudi Arabia

Corresponding Author: Badr Othman, Department of Preventive Dental Sciences, College of Dentistry, Taibah University, Al Madinah Al Munawwarah, Kingdom of Saudi Arabia, Phone: +966555625999, e-mail: bothman@taibahu.edu.sa

\section{INTRODUCTION}

A leading source of halitosis is odor-causing bacteria. The same types of anaerobic bacteria that are responsible for halitosis also cause gum infection. This gum infection leads to periodontitis if not treated or prevented. The persistent bad breath may be a warning sign of gum infection because it is caused by the plaque buildup in the cervical region of the tooth surfaces. The plaque is the accumulation of gram-negative anaerobic bacteria under the crevices of gingiva. Bacteria cause the formation of toxins, which irritate the gums. ${ }^{1}$

Chronic periodontal diseases have several etiological factors including dental plaque. Dental plaque, if allowed to build up, due to poor oral hygiene, can initiate the inflammatory process, as it becomes a medium for anaerobic bacteria., ${ }^{2,3}$

The oral cavity normally contains many types of bacteria. These bacteria balance each other and a result does not cause any odor in healthy individuals. However, due to poor oral hygiene, which often results in the overgrowth of some Sulphur producing species of bacteria, it results in halitosis. ${ }^{4}$

The range of flora patterns varies from person to person, and there is a very wide range of floral patterns, which are healthy. ${ }^{5}$ Halitosis has a significant impact on personal and social life. It is estimated to be the third most frequent reason for seeking dental aid after dental caries and periodontal diseases. ${ }^{6}$ Halitosis can lead to social embarrassment and even break a relationship. It can be a devastating social disability. People have been denied employment, failed in business and relegated to low social status because of it. ${ }^{7}$

Halitosis is socially unacceptable. Those who have halitosis are often unaware of it until friends or relatives have informed them. People who have been told that they suffer from bad breath may continuously worry and go into the psychosocial trauma. ${ }^{8,9}$ Halitosis is a condition that has health and social implications in the life of those who suffer from it. Cause of halitosis is mostly related to both systemic and oral conditions, but the oral causes predominate. ${ }^{10}$ Volatile sulfur compound produces gas is the primary source responsible for halitosis.They are formed as a result of gram-negative anaerobic bacteria putrefaction. Dorsum of the tongue and periodontal pockets are the major sites for oral halitosis. ${ }^{9}$ 
In today's society, there is undue pressure to look and smell good. Halitosis, depending on its severity, can negatively impact on a person's relationship both private and public within the society. As a result, halitosis is often referred to as a "social life killer" and persons go to utmost lengths in trying to treat and prevent it. ${ }^{11}$

The dentist is frequently involved in the management of patients who believe they have halitosis. It is estimated to be the third most frequent reason for visiting the dentist after tooth decay. In western society embarrassment and discomfort are the main reasons for seeking professional care. In the year 2000. American spent over $\$ 700$ million on mouthwash products and $\$ 625$ million on breath mints and other mouth fresheners. ${ }^{12}$

The objective of the study was to describe traumatic psychosocial impacts due to periodontal diseases and its relation to visiting dental clinics for aids from Madinah, Kingdom of Saudi Arabia.

\section{MATERIALS AND METHODS}

This was a cross-sectional study, and it was conducted on a random sample of 240 people. Among them, 9 participants were excluded because of the lack of information and total 231 participants (134 males and 97 females) included in the study. The data was collected using a structured questionnaire, which consisted of questions on the socio-demographic and oral health-related issues. The oral health-related issues included. They were also asked self-reported history of gingivitis, halitosis, smoking status, the frequency of brushing, dental visits, reasons for and treatment of gingivitis and halitosis. The questionnaire was distributed electronically among the people living in Madinah, Kingdom of Saudi Arabia.

The Statistical Package for Social Sciences (SPSS, version 21, Chicago, Illinois, USA) was used for data analysis and data processing. The characteristics of variables were described using frequency distribution. The chi-square test was used to assess associations between categorical variables. The $p$ value of less than 0.05 was considered statistically significant.

\section{RESULTS}

This study comprised of 231 subjects amowng them 134 were male and 97 were female and age ranged between 18 to 65 years and the mean age was 34.5. The sociodemographic data are shown in Table 1.

Most of the $163(70.6 \%)$ told the main reason for bad odor was poor oral hygiene and $162(70.1 \%)$ told to overcome the disease by home care.A common reason for visiting dentist was teeth pain (Figs 1 to 3 ).
Regarding the social problem, the percentage of ashamed was more male $67(50 \%)$ as compared to females $23(23.8 \%)$. There was a significant relationship between gender and their influence on social life $(\mathrm{p}=0.001)($ Table 2$)$.

Table 3 shows that 54 (53\%) participants were ashamed in social life who were suffered from gum problem. There was a significant relationship between the participants having gum problem and their influence in social life $p<0.001$.

Percentage of ashamed in social life was more $47 \%$ among unmarried participants as compared to married one, which is about $34 \%$ (Table 4 ).

There was not any significant relation with marriage and their influence in social life $\mathrm{p}=0.209$.

Among smokers, 50\% were ashamed in their social life as compared to non-smokers, which was $33.3 \%$. Table 5.

\section{DISCUSSION}

The present study investigated the psychosocial effect of people suffering from gingivitis and halitosis. Many patients having gum infection complain of bleeding gum and halitosis. Halitosis is one of the outcomes of gingivitis, which could lead on to periodontitis. Halitosis has been an age-old problem dating back to $1550 \mathrm{BC}$. Halito-

Table 1: Socio-demographic presentation of participants

\begin{tabular}{|c|c|c|}
\hline Gender & No & $\%$ \\
\hline Male & 134 & 58.0 \\
\hline Female & 97 & 42.0 \\
\hline \multicolumn{3}{|l|}{ Ethnicity } \\
\hline Saudi & 186 & 80.5 \\
\hline Non-Saudi & 45 & 19.5 \\
\hline \multicolumn{3}{|l|}{ Marital status } \\
\hline Married & 140 & 60.6 \\
\hline Unmarried & 81 & 35.1 \\
\hline Divorced & 7 & 3.0 \\
\hline Widowed & 3 & 1.3 \\
\hline \multicolumn{3}{|l|}{ Education level } \\
\hline Primary & 4 & 1.8 \\
\hline Intermediate & 8 & 3.5 \\
\hline High school & 41 & 17.7 \\
\hline Graduate and above & 178 & 77.1 \\
\hline \multicolumn{3}{|l|}{ Employment status } \\
\hline Employed & 102 & 44.1 \\
\hline $\begin{array}{l}\text { Professional work } \\
\text { (doctor/dentist) }\end{array}$ & 19 & 8.2 \\
\hline Teachers and faculty member & 49 & 21.2 \\
\hline Unemployed & 61 & 26.5 \\
\hline \multicolumn{3}{|l|}{ Income } \\
\hline$<3000$ & 67 & 29.0 \\
\hline $3001-5000$ & 32 & 13.9 \\
\hline $5001-7000$ & 20 & 8.7 \\
\hline $7001-10000$ & 30 & 13.0 \\
\hline
\end{tabular}




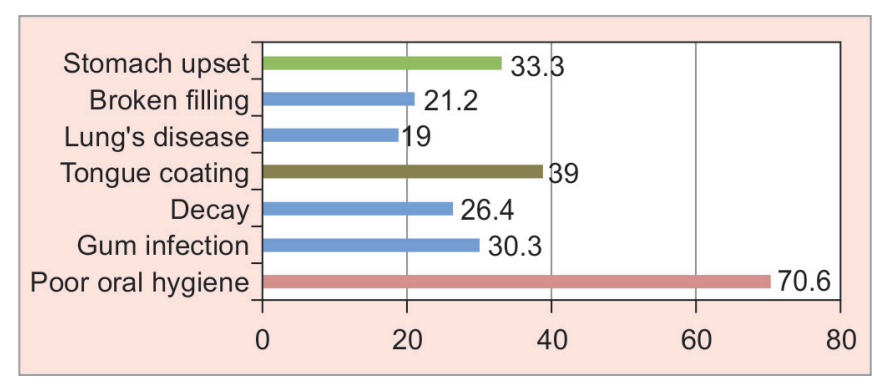

Fig 1: Percentage of participants gave the reasons for bad odor

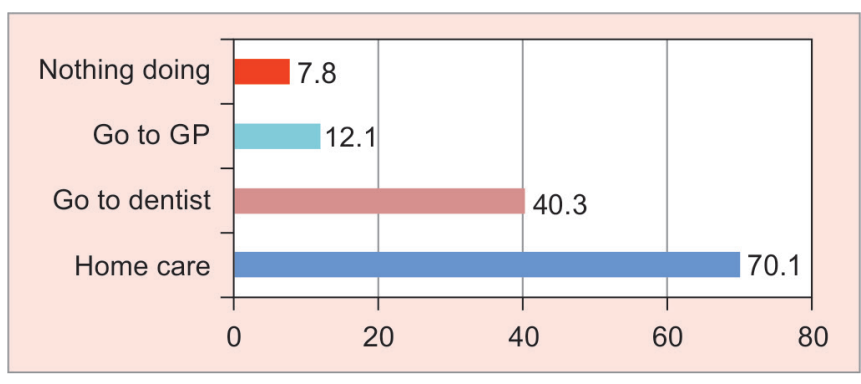

Fig 2: Percentage of participants told how to get rid of bad odor

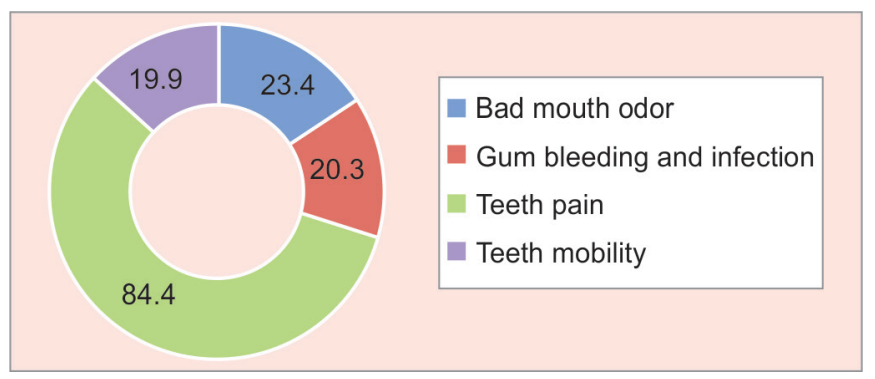

Fig 3: Percentage of participants told the reasons of visiting dentist

Table 2: Influences on the social life of the participant in relation to gender

\begin{tabular}{|c|c|c|c|c|c|c|c|c|c|c|}
\hline \multirow[b]{2}{*}{ Gender } & \multicolumn{2}{|c|}{$\begin{array}{l}\text { Very much } \\
\text { ashamed }\end{array}$} & \multicolumn{2}{|c|}{$\begin{array}{c}\text { Little } \\
\text { ashamed }\end{array}$} & \multicolumn{2}{|c|}{ Not ashamed } & \multicolumn{2}{|c|}{$\begin{array}{l}\text { Don't have } \\
\text { bad breath }\end{array}$} & \multicolumn{2}{|c|}{ Total } \\
\hline & $\mathrm{N}$ & $\%$ & $\mathrm{~N}$ & $\%$ & $\mathrm{~N}$ & $\%$ & $\mathrm{~N}$ & $\%$ & $\mathrm{~N}$ & $\%$ \\
\hline Male & 29 & 21.6 & 38 & 28.4 & 27 & 20.1 & 40 & 29.9 & 134 & 100 \\
\hline Female & 12 & 12.4 & 11 & 11.4 & 25 & 26.7 & 49 & 50.5 & 97 & 100 \\
\hline
\end{tabular}

Table 3: Gum problem influences on the social life of the participant

\begin{tabular}{|c|c|c|c|c|c|c|c|c|c|c|}
\hline \multirow{2}{*}{$\begin{array}{l}\text { Gum } \\
\text { problem }\end{array}$} & \multicolumn{2}{|c|}{$\begin{array}{l}\text { Very much } \\
\text { ashamed }\end{array}$} & \multicolumn{2}{|c|}{ Little ashamed } & \multicolumn{2}{|c|}{ Not ashamed } & \multicolumn{2}{|c|}{$\begin{array}{l}\text { Don't have } \\
\text { bad breath }\end{array}$} & \multicolumn{2}{|r|}{ Total } \\
\hline & $\mathrm{N}$ & $\%$ & $\mathrm{~N}$ & $\%$ & $\mathrm{~N}$ & $\%$ & $\mathrm{~N}$ & $\%$ & $\mathrm{~N}$ & $\%$ \\
\hline Yes & 23 & 22.5 & 31 & 30.4 & 31 & 30.4 & 17 & 16.7 & 102 & 100 \\
\hline No & 11 & 12.8 & 6 & 7.0 & 11 & 12.8 & 58 & 67.4 & & 86 \\
\hline
\end{tabular}

Table 4: Influences on the social life of the participant in relation with marital status

\begin{tabular}{|c|c|c|c|c|c|c|c|c|c|c|}
\hline \multirow{2}{*}{$\begin{array}{l}\text { Marital } \\
\text { Status }\end{array}$} & \multicolumn{2}{|c|}{$\begin{array}{l}\text { Very much } \\
\text { ashamed }\end{array}$} & \multicolumn{2}{|c|}{ Little ashamed } & \multicolumn{2}{|c|}{ Not ashamed } & \multicolumn{2}{|c|}{$\begin{array}{l}\text { Don't have } \\
\text { bad breath }\end{array}$} & \multicolumn{2}{|c|}{ Total } \\
\hline & $\mathrm{N}$ & $\%$ & $\mathrm{~N}$ & $\%$ & $\mathrm{~N}$ & $\%$ & $\mathrm{~N}$ & $\%$ & $\mathrm{~N}$ & $\%$ \\
\hline Married & 26 & 17.3 & 26 & 17.3 & 35 & 23.4 & 63 & 42.0 & 150 & 100 \\
\hline Unmarried & 15 & 18.5 & 23 & 28.5 & 17 & 21.0 & 26 & 32.0 & 81 & 100 \\
\hline
\end{tabular}

Table 5: Influences on the social life of the participant in relation with smoking

\begin{tabular}{|c|c|c|c|c|c|c|c|c|c|c|}
\hline \multirow[b]{2}{*}{ Smoking habit } & \multicolumn{2}{|c|}{$\begin{array}{l}\text { Very much } \\
\text { ashamed }\end{array}$} & \multicolumn{2}{|c|}{ Little ashamed } & \multicolumn{2}{|c|}{ Not ashamed } & \multicolumn{2}{|c|}{$\begin{array}{l}\text { Don't have } \\
\text { bad breath }\end{array}$} & \multicolumn{2}{|c|}{ Total } \\
\hline & $\mathrm{N}$ & $\%$ & $\mathrm{~N}$ & $\%$ & $\mathrm{~N}$ & $\%$ & $\mathrm{~N}$ & $\%$ & $\mathrm{~N}$ & $\%$ \\
\hline Smoker & 18 & 24.0 & 20 & 26.7 & 17 & 22.7 & 20 & 26.6 & 75 & 100 \\
\hline Non smoker & 23 & 14.7 & 29 & 18.6 & 35 & 22.4 & 69 & 44.3 & 156 & 100 \\
\hline
\end{tabular}

sis can be considered social stigma, which interferes, in on social and personal relationships. ${ }^{13}$ People suffering personal relationships. Not only is it a sign of ill health, from halitosis often create a barrier that separates them but it also results in psychological change impacting from their friends, colleagues, and peers in all aspects of 
their lives and has always been a source of concern when interacting in society. ${ }^{14}$

In this study, the majority of the participants described poor oral hygiene $(70.6 \%)$ and gum infection $(30.3 \%)$ was the reasons of bad mouth odor and get rid of this by doing home care (70.1\%). Gum disease is multifactorial, and oral hygiene is one of the factors to develop the diseases. It is essential to understand the factors to avoid the wrong conception regarding gum infection and halitosis. It has a significant impact on those who suffer from it or believe and it is estimated to be the third most frequent reason for visiting dentist to take dental aid after dental caries and periodontal diseases. ${ }^{15}$ Forty percent of participants told that by visiting dentist it could be solved Table 2. Many other studies had also found the similarity with the results of this study. ${ }^{16-19}$

Gum problem had always influenced on social life and females are more ashamed in the society due to it, but in our study percentage of females very much ashamed $12.4 \%$ were less as compared to males that were $21.6 \%$ (Table 3). This might be females were more particular about their look and esthetic so might be regularly visited the clinic as advised by the dentist and took care of oral hygiene. There was not any significant relationship with the marital status and age with the social stigma (feeling of ashamed) in the society.

The participant who had gum infection described that they felt ashamed in the society while taking with friends or relative. Many kinds of literature show that halitosis is one of the reasons for this and gum infection is one of the factors to develop the halitosis. In a previous study the youth of the University of Nairobi, School of Dental Sciences felt that halitosis has a negative impact on one's competition for a mate. ${ }^{19}$ The other studies also showed the relation of gum disease, halitosis, and social relation and found affected the quality of life. ${ }^{19-23}$

A total of fifty percent of smokers ashamed while interacting with the society as compared to nonsmokers. Tobacco smoke itself consists of volatile sulfur compounds (VSCs). ${ }^{24}$ The adverse effect of smoking on periodontal tissue may influence halitosis. Several publications have demonstrated a significant association between VSCs and periodontal diseases. ${ }^{25-27}$

\section{CONCLUSION}

The patients who had gum diseases and smoking developed more psychosocial effect in the society, and it is due to halitosis develop either due to gum disease or smoking. So the main reason of psychosocial trauma is that indirect effect of halitosis, which produced due to gum infection.

People suffering from gingivitis and halitosis go to psychological trauma and they need a clinician to solve their problem

\section{ACKNOWLEDGMENT}

Author would like to thanks Dr Mohammad Sami Ahmad, Associate Professor of Dental Public Health, Department of Preventive Dental Sciences for helping me in statistical analysis and reviewing the manuscript.

\section{REFERENCES}

1. Sundararajan S, Muthukumar S, Rao SR. Relationship between depression and chronic periodontitis. J Indian SocPeriodontol 2015;19(3):294-296.

2. Peruzzo DC, Benatti BB, Ambrosano GMB, Nogueira-Filho GR, Sallum EA et al. A systemic review of stress and psychological factors as possible risk factors for periodontal disease. J Periodontol 2007;78:1491-1504.

3. Cayci E, Guzeldemir-Akcakanat E. The relationship between Psychosocial factors and periodontal disease. Dentistry 4:223.

4. Pérez-Chaparro PJ, Gonçalves C, Figueiredo LC, Faveri M, Lobão E, Tamashiro N, et al. Newly identified pathogens associated with periodontitis: A systematic review. J Dent Res 2014;93(9):846-858.

5. Bosy A. Oral malodor: Philosophical and practical aspects. J Can Dent Assoc 1997;63(3):196-201.

6. Loesche WJ, Kazor C. Microbiology and treatment of halitosis. Periodontology 2000; 2002;28:256-279.

7. Yaegaki K, Coil JM. Examination, classification and treatment of halitosis, clinical perspectives. J Can Dent Assoc 2000;66:257-261.

8. Arora L, Sharma A. A study to find out the Dental and Associated Psychosocial Factors in Patients with Halitosis. Delhi Psychiatry Journal 2012;15(1):122-129.

9. Khaira N, Palmer RM, Wilson RF, Scott DA, Wade WG. Production of volatile sulphur compounds in diseased periodontal pockets is significantly increased in smokers. Oral Dis 2000;6:371-375.

10. Halitosis defined by Wikipedia Encyclopedia. Available at:http://www.en.wikipedia.org/wiki/halitosis.com. Accessed 19 November 2011.

11. De Sousa A Psychological issues in acquired facial trauma. Indian J PlastSurg 2010;43(2):200-205.

12. Beertsen W, Mcculloch Christopher AG, Sodek J. Theperiodontal ligament: a unique, multifunctional connectivetissue. Periodontology 2000. 1997;13:20-40

13. Sanz M, Roldan S, Herrera D. Fundamentals of breath malodor. J Contemp Dent Pract 2001;2(4):1-17.

14. Bosy A. Oral malodor: philosophical and practical aspect. J Can Dent Assoc 1997;63(3):196-201.

15. Loesche WJ, Kazor C. Microbiology, and treatment of halitosis. Periodontology 2000. 2002;28:256-279.

16. Bornstein MM, Kislig K, Hoti BB, Seemann RL. A prevalence of halitosis in the population of the city of Bern, Switzerland: A study comparing self-reported and clinical data. Eur J Oral Sci 2009;117:261-267.

17. Bornstein MM, Stocker BL, Seemann R, Burgin WB, Lussi A. Prevalence of halitosis in young male adults: A study in Swiss Army Recruits comparing self-reported and clinical data. J Periodontol 2009;80(1):24-31.

18. Needleman I, McGrath C, Floyd P, Biddle P, Biddle A. Impact of oral health on the life quality of periodontal patients. J CinPeriodontol 2004;31:454-457.

19. The Ministry of Health, Brazil National Oral Health Survey 2010; main results. 1-92. 
20. Omili M, Ofili AN, Omuemu V, Oral health perception among officers and men of the Nigerian prisons service. Eur J Gen Dent 2013;2:252-256.

21. Ng SK, Leung WK. Oral health-related quality of life and periodontal status. Community Dent Oral Epidemiol 2006; 34:114-122.

22. Jowett AK, Orr MTS, Rawlinson A, Robinson PG. Psychosocial impact of periodontal disease and its treatment with 24-h root surface debridement. J ClinPeriodontol 2009;36:413-418.

23. Abrahamsson KH, Wennstrom JL, Hallberg U. Patient's view on periodontal disease: attitudes to oral health and expectancy of periodontal treatment: a qualitative interview study. Oral Health Prev Dent 2007;6:209-216.

24. Sangkheaw S. Effect of smoking on periodontal tissues and halitosis. J Dent AssocThai 2007;57:275-283.

25. Tonzetich J. Oral malodor: an indicator of health status and oral cleanliness. Int Dent J 1978;28:309-319.

26. Rizzo AA. The possible role of hydrogen sulfide in human periodontal disease I. Hydrogen sulfide production in periodontal pockets. Periodontics 1967;5:233-236.

27. Rosenberg M. bad breath and periodontal disease: how related are they? J ClinPeriodontol 2006;33:29-30. 